Jesuit Science in America: The Bulletin of the American Association of Jesuit Scientists (1922-66)

Author: Francisco Malta Romeiras

Source: Engaging Sources: The Tradition and Future of Collecting History in the Society of Jesus (Proceedings of the Symposium held at Boston College, June 11-13, 2019)

Edited by: Cristiano Casalini, Emanuele Colombo, and Seth Meehan

ISBN: 978-1-947617-09-4

Published by: Institute of Jesuit Sources

Originally Published: March 1, 2021

https://doi.org/10.51238/ISJS.2019.24

Provided in Open Access by the Institute for Advanced Jesuit Studies at Boston College.

The Institute of Jesuit Sources, specializes in preserving, maintaining, and expanding for scholars around the world important texts and studies in Jesuit history, spirituality, and pedagogy.

Visit our website at https://jesuitsources.bc.edu 


\title{
Jesuit Science in America: The Bulletin of the American Association of Jesuit Scientists (1922-66)
}

\author{
FRANCISCO MALTA ROMEIRAS
}

\section{Introduction}

In August 1922, a group of teachers from East Coast colleges and universities established the American Association of Jesuit Scientists. Although it was intended for private circulation, the association's journal, the Bulletin of the American Association of Jesuit Scientists (1922-66), had a surprising longevity. For forty-three years, the Bulletin published proceedings of the Jesuits' annual meetings, obituaries, and biographies of distinguished Jesuit scientists, and abstracts and longer research articles on mathematics, physics, seismology, chemistry, and biology.

In 1984, Jesuit scholar Frederick A. Homann (1929-2011) emphasized the importance of the Bulletin as a source for the history of Catholic education in the United States. ${ }^{1}$ In his short, yet seminal essay, the professor of mathematics at St. Joseph's University asserted that the journal was initially influenced by European Jesuits and that the American brethren engaged in "limited but promising" scientific activity in the 1920s and 1930s. ${ }^{2}$ After the Second World War, the Jesuits had access to government funds and "large numbers of their best men, both priests and scholastics" were sent for doctoral studies at secular universities such as Harvard, Johns Hopkins, Pennsylvania, Stanford, and MIT. Paradoxically, Jesuit schools

Acknowledgments: in November 2018, I spent a few days at the Institute for Advanced Jesuit Studies studying the first issues of the Bulletin of the American Association of Jesuit Scientists. This research continued in Lisbon thanks to the much-desired digitization of the sixty-six volumes of the Bulletin by Boston College libraries. For these reasons, I want to thank the Institute for Advanced Jesuit Studies, the Saint Faber Jesuit Community, Boston College Libraries, and the Portal of Jesuit Studies. A first version of this article was read at the 2019 International Symposium on Jesuit Studies and benefited greatly from the discussion at the session "Jesuit Sources in 20th-Century Public Debates." Since the very first days, Seth Meehan was an invaluable help. He read earlier versions of the paper, suggested bibliography, and was a careful and patient editor. The comments and suggestions from the anonymous referees were very useful in refining and sharpening the argument of this article.

${ }^{1}$ Frederick. A. Homann, "A Source for the History of American Catholic Education: The Jesuit Science Bulletin," Records of the American Catholic Historical Society of Philadelphia 95 (1984): $27-35$.

${ }^{2}$ Homann, "Source for the History of American Catholic Education," 30, 33. 
failed to develop "first-rate graduate programs" in astronomy, seismology, meteorology, and chemistry, even though these were disciplines in which they had traditionally excelled. ${ }^{3}$

This article expands on the idea that the Bulletin is a critical source for the history of Catholic education and offers a more complex, and less bleak, portrayal of Jesuit science in America. A first survey of the Bulletin reveals, among other things, the growth of the American Association of Jesuit Scientists, the increasing professionalization of Jesuit scholars, and the financial and human resources needed for the construction, renovation, and daily work in the chemistry laboratories, astronomical observatories, and seismological stations across the country. Besides highlighting the most frequent topics and prolific authors in each period, some episodes will receive particular attention, namely the national and international context behind the Bulletin's foundation in 1922, the debate around academic professionalism in the 1930s, and the celebration of the four hundredth anniversary of the Society of Jesus in 1940. Finally, there will also be an appraisal of the Jesuits' views on controversial topics such as the warfare between science and religion, evolution, and eugenics.

As well as offering new perspectives on the history of Jesuit science and education, this article hopes to contribute to the debate about the role of science in the building of an American Catholic culture and to challenge, even if partially, the "inadequacy of Catholic scholarship" caused by the "self-imposed ghetto mentality which prevents them from mingling as they should with their non-Catholic colleagues, and in their lack of industry and the habits of work," as John Tracy Ellis (1905-92) famously claimed in $1955 .{ }^{4}$

\section{The Foundation of a Science Bulletin}

On August 21, 1922, a group of East Coast Jesuits gathered at Canisius College, Buffalo, to discuss ways of improving the teaching of science at their colleges. During that meeting, they decided to create an association - provisionally called Association of Science and Mathematics Teachers of the New York-Maryland Province - to promote the "teaching of Science and Mathematics in our schools and colleges by mutual encouragement and stimulation and the presentation, discussion, and publication of papers." ${ }^{n}$ The following year, the group of science teachers

\footnotetext{
${ }^{3}$ Homann, "Source for the History of American Catholic Education," 31, 33.

${ }^{4}$ John Tracy Ellis, "The American Catholic and the Intellectual Life," Thought 30 (1955): 351-88, here 385-86. See also Ronald A. Binzley, "American Catholicism's Science Crisis and the Albertus Magnus Guild, 1953-1969,” Isis 98 (2007): 695-723.

${ }^{5}$ Joseph P. Kelly, "Temporary Constitution," Bulletin of the Association of Science and Mathematics Teachers of the New York-Maryland Province 1, no. 1 (1922): 3-4. The constitution was ratified
} 
met at Fordham University, New York, where they reelected Michael J. Ahern (1877-1951) ${ }^{6}$ as president (in office 1922-25) and agreed on a shorter, more suitable and inclusive name: American Association of Jesuit Scientists (AAJS). The meetings of AAJS were held at Jesuit colleges and universities of the provinces of New York, Maryland, and New England, including Fordham (New York), Georgetown (Washington, DC), Fairfield (Connecticut), Scranton (Pennsylvania), Loyola (Baltimore), Holy Cross (Worcester), St. Joseph's (Philadelphia), and Boston College. With the exception of the difficult years between 1942 and 1945, AAJS convened annual meetings until 1966 (see fig. 1). ${ }^{7}$

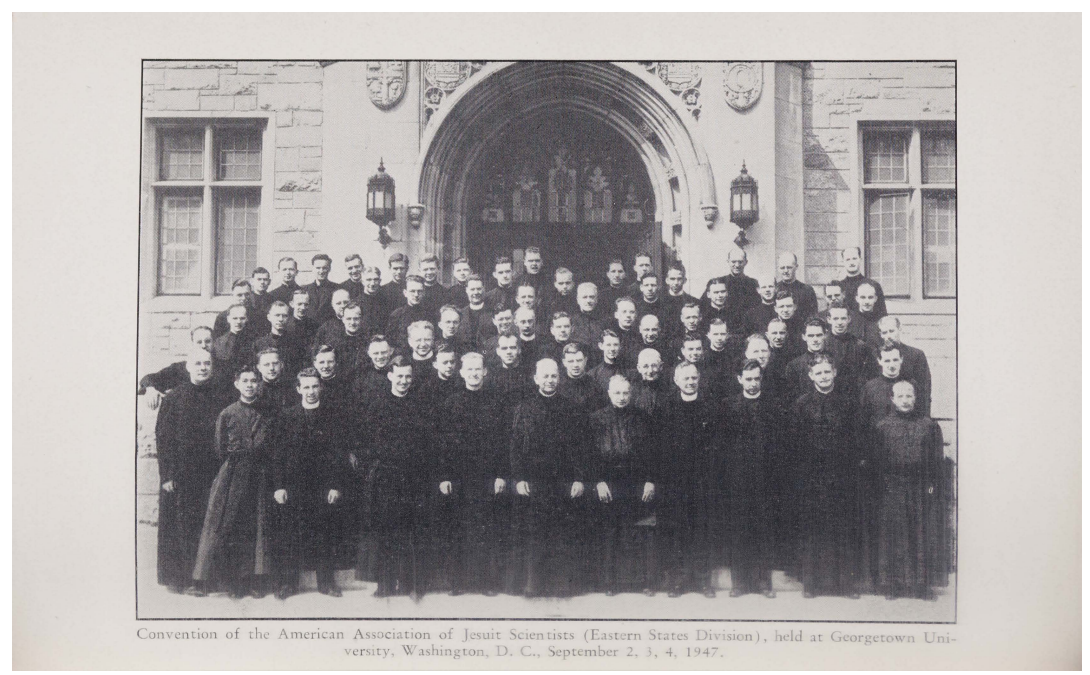

Figure 1. Official photograph of the twenty-second annual meeting of the Association of American Jesuit Scientists. Georgetown University, Washington, DC, September 24, 1947. Bulletin of American Association of Jesuit Scientists 25, no. 1 (1947): 4.

the following year: "Constitution of the American Association of Jesuit Scientists (Eastern States Division)," Proceedings of the American Association of Jesuit Scientists (Fordham University, 1923): 7-10.

${ }^{6} \mathrm{I}$ have included some basic biographical information for the most relevant Jesuits referred to in this article - date and place of birth, date of entering the novitiate, and date and place of death. Michael J. Ahern: born May 25, 1877, New York; entered September 7, 1896; died June 5, 1951, Boston (Charles O'Neill and Joaquín M. Domínguez, eds., Diccionario histórico de la Compañía de Jésus: Histórico-biográfico [henceforth DHCJ], 4 vols. [Rome: Institutum Historicum Societatis Iesu, 2001], 1:26).

${ }^{7}$ During those years, the Association of American Jesuit Scientists convened regional meetings at St. Joseph's High School, Philadelphia, and Weston College, Massachusetts (1942); Fordham University and Weston College (1943); and St. Joseph's High School (1944). 
From its foundation, one of the main purposes of AAJS was to "publish a monthly bulletin on scientific topics" (fig. 2). ${ }^{8}$ As Thomas J. Brown (1891-1952) ${ }^{9}$ expounded in the first editorial, "the bulletin was to include news about the various members of the Association or their scientific methods, studies, and other activities." By publishing such a periodical, he continued, each member "may know what is being done in other parts of the province, suggest improvements in various scientific lines, acquaint others with a particular instrument, experiment, book or discovery that may be just the thing a fellow teacher is seeking." Brown knew the success of this venture would require the participation of the larger community. Therefore, he urged the members of AAJS to contribute with "live, up-to-date articles on any scientific topic."10

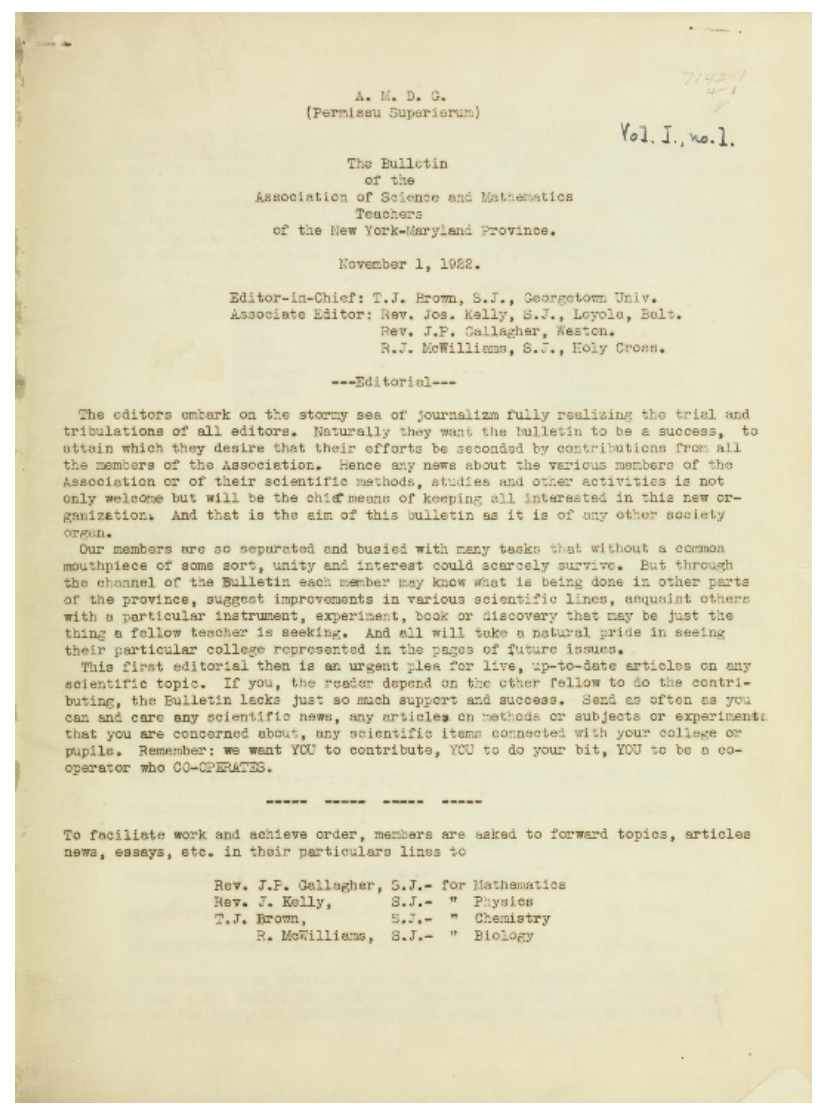

Figure 2. The Bulletin of the Association of Science and Mathematics

Teachers of the New York-Maryland Province 1, no. 1 (1922).

\footnotetext{
${ }^{8}$ Thomas J. Brown et al., "Editorial," Bulletin of the Association of Science and Mathematics Teachers of the New York-Maryland Province 1, no. 1 (1922): 1-3, here 2.

${ }^{9}$ Thomas J. Brown: born April 10, 1891, Batavia, New York; entered September 7, 1914; died June 9, 1952, New York (Rufo Mendizábal, Catalogus defunctorum in renata Societate Iesu ab a. 1814 ad a. 1970 [Rome: Apud Curiam Praepositi Generalis, 1972], 25,821).

${ }^{10}$ Brown et al., "Editorial," 1.
} 
Brown's appeal was largely successful. For forty-three years, the Bulletin of the American Association of Jesuit Scientists published short news articles and reports, abstracts and longer articles on a variety of subjects, ranging from mathematics, astronomy, chemistry, and seismology to evolution and eugenics. ${ }^{11}$ Besides issuing the Bulletin, AAJS also published the Proceedings of its annual meetings (fig. 3). Initially, the Proceedings were printed as unnumbered issues (1923-28), but after 1929 they began to be incorporated into the first number of each volume of the Bulletin, which was usually printed in September/October.

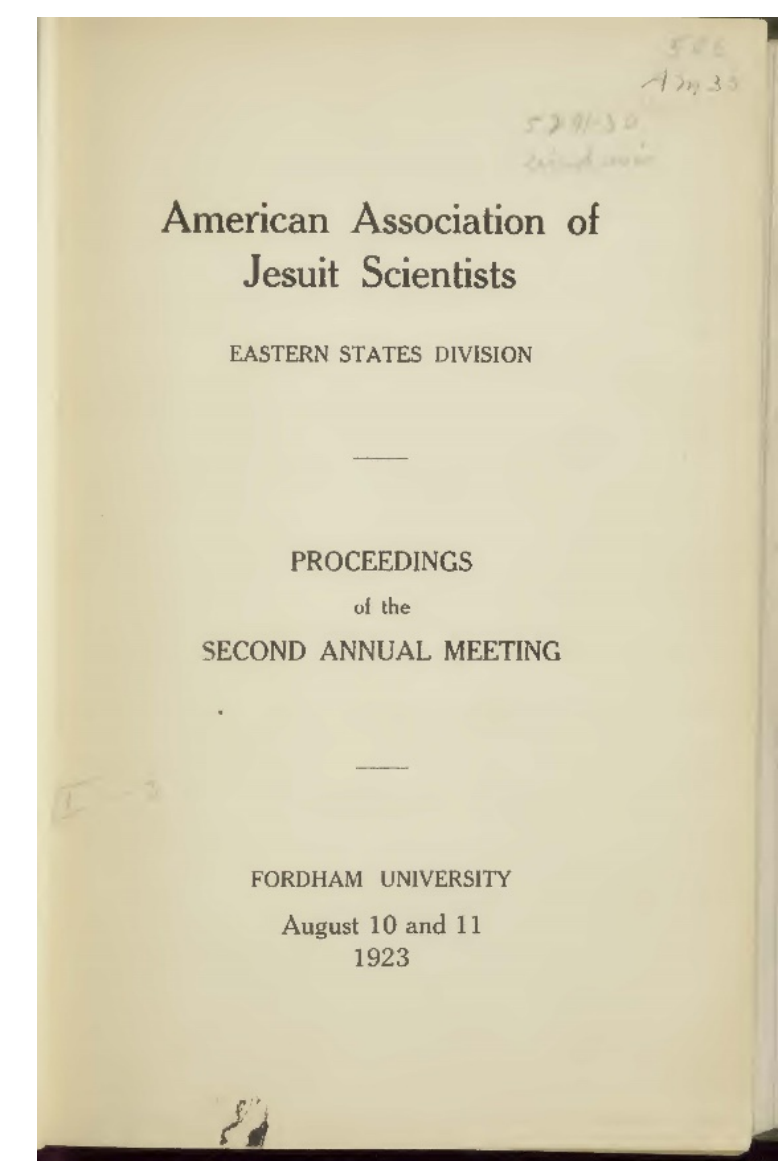

Figure 3. Proceedings of the Second Annual Meeting of the American Association of Jesuit Scientists-Eastern State Division (New York: Fordham University, 1923).

\footnotetext{
${ }^{11}$ Bulletin of the American Association of Mathematics Teachers of the New York-Maryland Province (1922), 1 issue (mimeographed); Bulletin of the American Association of Jesuit Scientists, Eastern Section (1923-47), 105 issues (mimeographed, 1923-28; printed, 1929-May 1947); Bulletin of the American Association of Jesuit Scientists, Eastern States Division (September 1947-66, fifty-nine issues [printed]).
} 
The foundation of a bulletin dedicated to scientific topics by the American Jesuits in the 1920s, and its publication for more than forty consecutive years, must be understood within a broader intellectual and historical context. The Jesuits were deeply aware of the debates that had divided Catholic elites in Europe and in the United States in the previous decades, especially those regarding the condemnation of modernism, the endorsement of New Scholasticism, and the centennial dispute on conciliarism, ultramontanism, and papal infallibility. ${ }^{12}$ Furthermore, Charles W. Eliot's (1834-1926) refusal to admit graduates from Catholic colleges to Harvard Law School in 1893, and the subsequent controversies, contributed to a long-lasting portrayal of Catholic education as backward and inadequate. ${ }^{13}$ By surveying the Bulletin, it is possible to grasp not only the remnants of those disputes but also to scrutinize the Jesuits' sustained efforts to counter these accusations in an increasingly secularized society well into the mid-twentieth century. ${ }^{14}$

When the first issue of the Bulletin came out, the Jesuits already had a long tradition of publishing periodicals. ${ }^{15}$ Before the universal suppression of the Society of Jesus in 1773, they edited the encyclopedic Journal de Trévoux (Journal of Trévoux [1701-67]) and Storia letteraria d'Italia (Literary history of Italy [175059]). After the restoration, Italian Jesuits revived this determination to publish learned periodicals and created La civiltà cattolica (Catholic civilization) in $1850 .{ }^{16}$ Meant to provide a careful and logical explanation of Catholic doctrine and moral principles, La civiltà cattolica's success inspired the foundation of other cultural magazines across Europe, such as Etudes (Studies [France, 1856]), The Month (England, 1864), Stimenn der Zeit (Voices of the times [Germany, 1865]), and Razón y fé (Reason and faith [Spain, 1901]). As well as being keepers of orthodoxy, faith, and morals, these journals were expected to serve as a practical means to promote a Catholic culture in Europe. ${ }^{17}$ In its early years, Razón y fé was also keen on documenting the everyday work of Jesuit scientists in Spain. ${ }^{18}$ The articles published by Razon y fé portrayed the Jesuits as active and modern scientists in their own right and field of expertise.

\footnotetext{
${ }^{12}$ John W. O'Malley, Vatican I: The Council and the Making of the Ultramontane Church (Cambridge, MA: Belknap Press of Harvard University Press, 2018).

${ }^{13}$ Philip Gleason, Contending with Modernity: Catholic Higher Education in the Twentieth Century (New York: Oxford University Press, 1995); John T. McGreevy, Catholicism and American Freedom: A History (New York: W. W. Norton, 2004); Catherine O'Donnell, Jesuits in the North American Colonies and the United States: Faith, Conflict, Adaptation (Leiden: Brill, 2020), 63-68.

${ }^{14}$ Brad S. Gregory, The Unintended Reformation: How a Religious Revolution Secularized Society (Cambridge, MA: Belknap Press of Harvard University Press, 2012), 298-364.

${ }^{15}$ Francisco Malta Romeiras, Jesuits and the Book of Nature: Science and Education in Modern Portugal (Leiden: Brill, 2019), 101-6.

16 "Il giornalismo moderno ed il nostro programma," La civiltà cattolica 1 (1850): 5-24.

${ }^{17}$ Romeiras, Jesuits and the Book of Nature, 101-6.

${ }^{18}$ See, for instance, Juan Granero, "El observatorio astronómico, geodinâmico y meteorológico de Granada," Razón y fé 3 (1902): 222-25; Granero, "Observatorio de Granada," Razón y fé 3 (1902): 512-20; Ramón Martínez, "Observatorio de Granada: Sección meteorológica," Razón y fé 4 (1902):
} 
In the United States, the Jesuits issued the weekly magazine America (1909-) and the devotional Messenger of the Sacred Heart (1866-). But whereas these journals enjoyed nationwide distribution, the Bulletin was meant for "private circulation." In this sense, it was similar to Woodstock Letters (1872-1969) and Jesuit Educational Quarterly (1938-70). Because it was not created to uphold the Catholic faith in a secular milieu or to be the official publication of the Apostleship of Prayer, but rather to engage and promote cooperation between Jesuit teachers and scholars, its limited circulation is not surprising. The Bulletin was not the only scientific publication of the Society of Jesus in America in this period, as it shared the stage with the more specialized Bulletin of the Jesuit Seismological Association. Created in 1925 by the renowned seismologist James B. Macelwane (1883-1956), ${ }^{19}$ the Jesuit Seismological Network had a central station at St. Louis University. Besides collecting and analyzing the data from the network of Jesuit observatories established in the United States, this observatory assembled data from other stations to determine the time and place of earthquakes across the globe and published its important findings in a journal "much appreciated by seismologists worldwide." 20

The Bulletin covered a similar range of topics to the Portuguese journal Brotéria (1902-2002) and the Spanish magazine Ibérica (1913-36; 1945-2004). Founded in 1902 as a taxonomy journal of a boarding school in the countryside, Brotéria was the first Jesuit journal exclusively dedicated to science. During its centennial existence, Brotéria printed around 1,300 scientific research articles on botany, zoology, plant breeding, biochemistry, and genetics and was acknowledged as one of the leading biology journals in twentieth-century Portugal. ${ }^{21}$ Created in 1913 at the Observatorio del Ebro, and with articles on physics, astronomy, meteorology, seismology, and geophysics, the weekly magazine Ibérica was one of the most popular scientific magazines in Spain. ${ }^{22}$ But, unlike Ibérica and Brotéria, the

478-90; Granero, “Observatorio de Granada: Sección astronómica,” Razón y fé 5 (1903): 339-47; Baltasar Merino, "Viajes de herborización por Galicia," Razón y fé 1 (1901): 95-98; Razón y fé 2 (1902): 82-89; Razón y fé 2 (1902): 367-73; Razón y fé 4 (1902): 82-93; Razón y fé 5 (1903): 34860.

19 James B. Macelwane: born September 28, 1883, Port Clinton, Ohio; entered August 31, 1903; died February 15, 1956, St. Louis (DHCJ 3:2454-55). For a lengthier biographical note, see Agustín Udías, Jesuit Contribution to Science: A History (Dordrecht: Springer, 2015), 203-7.

${ }^{20}$ Udías, Jesuit Contribution to Science, 181. For a history of the Jesuit Seismological Association, see John Joseph Lynch, "The Jesuit Seismological Association," Bulletin of the American Association of Jesuit Scientists 40, no. 1 (1963): 34-39; Agustín Udías, Jesuits and the Natural Sciences in Modern Times, 1814-2014 (Leiden: Brill, 2019), 62-68; Udías, Searching the Heavens and the Earth: The History of Jesuit Observatories (Dordrecht: Kluwer Academic, 2003), 103-24.

${ }^{21}$ Romeiras, Jesuits and the Book of Nature, 101-91.

22 Pascual Bolufer, "Science and Technology in the 20th Century as Seen through the Journal Ibérica (1914-2003)," Contributions to Science 7 (2011): 185-90; Maria Genescà-Sitjes, "Ibérica Magazine (1913-2004) and the Ebro Observatory," Contributions to Science 9 (2013): 159-68; Nestor Herran, "Science to the Glory of God': The Popular Science Magazine Ibérica and Its Coverage of Radioactivity," Science \& Education 21 (2012): 335-53. 
Bulletin always kept its regional subheading, was intended for private circulation, and the correspondents were only Jesuits. ${ }^{23}$

\section{The Roaring Twenties}

In the 1920s, four Jesuit scholars served as editors of the Bulletin (see table 1) and membership of AAJS grew from eighty-three associates in 1923 to 105 in 1930. During Henry M. Brock's (1876-1966) ${ }^{24}$ tenure as editor-in-chief, the journal was mimeographed and was based at Weston, Massachusetts (1923-28). Because AAJS had been created to promote the "teaching of Science and Mathematics in our schools and colleges," 25 the Bulletin dedicated a considerable number of articles to this matter. Jesuit teachers often shared their reflections or asked for advice on practical matters, such as the difficulties of hiring efficient graduate assistants for biology departments, the current standing of demonstrations during lectures, or the approval of laboratory manuals. ${ }^{26}$ Several papers dealt specifically with the Philippines, the most important American Jesuit mission in this period. ${ }^{27}$ These essays focused on the Manila Observatory and the Ateneo. ${ }^{28}$ The papers were "of interest because they bring out some of the special problems met with in teaching science in the Philippines and the methods employed in solving them." For Brock, they "should prove helpful not only to those who may be called upon later to take up science work in Our distant Mission in the Far East but also to those teaching here

\footnotetext{
${ }^{23}$ Although AAJS appointed Jesuit correspondents from across the country in 1935, the Bulletin continued to carry a regional label until its publication ceased in 1966.

${ }^{24}$ Henry M. Brock: born May 8, 1876, Boston; entered October 14, 1900; died September 8, 1966, Brookline (Mendizábal, Catalogus defunctorum, 30,664).

25 "Constitution of the American Association of Jesuit Scientists," no. 2.

${ }^{26}$ Joseph F. Busam, "Overcoming the Difficulties of Biological Laboratory Work," Bulletin of the American Association of Jesuit Scientists 1, no. 3 (1924): 7-8; John A. Daly, "Lecture Demonstrations," Bulletin of the American Association of Jesuit Scientists 1, no. 3 (1924): 8; Daly, "Charts for Lectures," Bulletin of the American Association of Jesuit Scientists 1, no. 3 (1924): 8-9; Anthony J. MacCormack, "Sample of a Laboratory Manual in Zoology," Bulletin of the American Association of Jesuit Scientists 2, no. 4 (1925): 43-45.

${ }^{27}$ For a history of the Jesuits in the Philippines, see McGreevy, Catholicism and American Freedom, 179-209.

${ }^{28}$ John A. Pollock, "Marking in Biology," Bulletin of the American Association of Jesuit Scientists 2, no. 3 (1925): 32; Henry B. McCullough, "The General Chemistry Course at the Ateneo de Manilla," Bulletin of the American Association of Jesuit Scientists 2, no. 3 (1925): 33-34; Bernard F. Doucette "A Brief History of the Manila Observatory (Part I)," 1, no. 2 (1925): 6-10; Doucette, "Equipment of the Manila Observatory," Bulletin of the American Association of Jesuit Scientists 3, no. 4 (1926): 42-44; "Course in Sugar Chemistry at the Ateneo, Manilla," Bulletin of the American Association of Jesuit Scientists 3, no. 5 (1926): 59.
} 
in the United States." ${ }^{29}$ Finally, there were also announcements of articles or textbooks by Jesuits, such as Theodor Wulf's (1868-1946) Lehrbuch der Physik (Physics textbook [Freiburg, 1926]). ${ }^{30}$

Table 1. Editors of the Bulletin of the American Association of Jesuit Scientists, 1922-66

\begin{tabular}{|c|c|c|c|}
\hline Year & $\begin{array}{l}\text { Editor-in-chief of the } \\
\text { Bulletin }\end{array}$ & Institution & President of AAJS \\
\hline 1922-23 & Thomas J. Brown & Georgetown University & Michael J. Ahern \\
\hline 1923-24 & Henry M. Brock & Weston College & Michael J. Ahern \\
\hline 1924-25 & Henry M. Brock & Weston College & Michael J. Ahern \\
\hline $1925-26$ & Henry M. Brock & Weston College & George F. Strohaver \\
\hline 1926-27 & Henry M. Brock & Weston College & George F. Strohaver \\
\hline $1927-28$ & Henry M. Brock & Weston College & Edward C. Phillips \\
\hline 1928-29 & John L. Gipprich & Georgetown University & Richard B. Schmitt \\
\hline 1929-30 & Joseph P. Merrick & Holy Cross College & Richard B. Schmitt \\
\hline 1930-31 & Richard B. Schmitt & Loyola College, Baltimore & Clarence E. Shaffrey \\
\hline 1931-32 & Richard B. Schmitt & Loyola College, Baltimore & Clarence E. Shaffrey \\
\hline 1932-33 & Richard B. Schmitt & Loyola College, Baltimore & Joseph J. Sullivan \\
\hline 1933-34 & Richard B. Schmitt & Loyola College, Baltimore & Thomas H. Quigley \\
\hline 1934-35 & Richard B. Schmitt & Loyola College, Baltimore & Francis W. Power \\
\hline 1935-36 & Richard B. Schmitt & Loyola College, Baltimore & Henry M. Brock \\
\hline 1936-37 & Richard B. Schmitt & Loyola College, Baltimore & Charles A. Berger \\
\hline $1937-38$ & Richard B. Schmitt & Loyola College, Baltimore & George A. O'Donnell \\
\hline 1938-39 & Richard B. Schmitt & Loyola College, Baltimore & Emeran J. Kolkmeyer \\
\hline $1939-40$ & Richard B. Schmitt & Loyola College, Baltimore & John A. Tobin \\
\hline $1940-41$ & Anthony G. Carroll & Boston College & Richard B. Schmitt \\
\hline $1941-42$ & Gerald F. Hutchinson & Weston College & Edward C. Phillips \\
\hline $1942-43$ & Gerald F. Hutchinson & Cheverus High School, Maine & Edward C. Phillips \\
\hline $1943-44$ & Gerald F. Hutchinson & Cheverus High School, Maine & Edward C. Phillips \\
\hline $1944-45$ & Gerald F. Hutchinson & Cheverus High School, Maine & Edward C. Phillips \\
\hline $1945-46$ & Gerald F. Hutchinson & Cheverus High School, Maine & Edward C. Phillips \\
\hline $1946-47$ & Gerald F. Hutchinson & Cheverus High School, Maine & Frederick W. Sohon \\
\hline
\end{tabular}

${ }^{29}$ Bulletin of the American Association of Jesuit Scientists 2, no. 3 (1925): 34.

30 "Publications: A New Jesuit Textbook of Physics," Bulletin of the American Association of Jesuit Scientists 4, no. 3 (1927): 35; "Fr. Wulf's New Text Book of Physics," Bulletin of the American Association of Jesuit Scientists 4, no. 4 (1927): 40-41. Wulf was a pioneer in the study of cosmic rays, and his textbook was translated into English, French, and Spanish: Udías, Jesuit Contribution to Science, 217-18. 


\begin{tabular}{|l|l|l|l|}
\hline $1947-48$ & Gerald F. Hutchinson & Cheverus High School, Maine & Bernard A. Fiekers \\
\hline $1948-49$ & Bernard A. Fiekers & Holy Cross College & John A. Frisch \\
\hline $1949-50$ & Bernard A. Fiekers & Holy Cross College & John A. Frisch \\
\hline $1950-51$ & John J. McCarthy & Weston College & Francis J. Heyden \\
\hline $1951-52$ & John J. McCarthy & Weston College & Michael P. Walsh \\
\hline $1952-53$ & John J. McCarthy & Weston College & John S. O'Connor \\
\hline $1953-54$ & John J. McCarthy & Boston College & Thomas J. Smith \\
\hline $1954-55$ & John J. McCarthy & Boston College & George J. Hilsdorf \\
\hline $1955-56$ & John J. McCarthy & Boston College & John P. Delaney \\
\hline $1956-57$ & Bernard A. Fiekers & Holy Cross College & Gerald F. Hutchinson \\
\hline $1957-58$ & Bernard A. Fiekers & Holy Cross College & Joseph F. Mulligan \\
\hline $1958-59$ & Bernard A. Fiekers & Holy Cross College & Joseph A. Duke \\
\hline $1959-60$ & Bernard A. Fiekers & Holy Cross College & James K. Connolly \\
\hline $1960-61$ & Bernard A. Fiekers & Holy Cross College & Clarence Schubert \\
\hline $1961-62$ & James F. Smith & Woodstock College & James L. Harley \\
\hline $1962-63$ & Charles L. Currie & Woodstock College & James W. Skehan \\
\hline $1963-64$ & George V. Coyne & Woodstock College & James J. Ruddick \\
\hline $1964-65$ & George V. Coyne & Woodstock College & James J. Ruddick \\
\hline $1965-66$ & James F. Gilroy & Woodstock College & James J. Fischer \\
\hline
\end{tabular}

The gatherings of Jesuit scholars, on both sides of the Atlantic, the construction of science facilities, and the purchase of new instruments were recurrent themes. ${ }^{31}$ In 1924, for instance, there was the replacement of a "small old equatorial telescope" in the Woodstock observatory with "a larger instrument with improved mount and clock drive." The new telescope had been used in August to "observe the planet Mars at its opposition," and the observatory had "been much improved" by the installation of electric light. ${ }^{32}$ In 1926, the journal advertised that Major M. J. Connolly had made a donation of $\$ 15,000$ to equip St. Louis University with a "seismographic station for the study of both local and distant earthquake shocks." "33 Finally, in 1925, the journal announced plans to build a new "Institute of Chemo-

\footnotetext{
31 "Jesuit Scientists from Europe Visit the Province," Bulletin of the American Association of Jesuit Scientists 2, no. 1 (1924): 12; "Important Meeting of Ours in Rome," Bulletin of the American Association of Jesuit Scientists 2, no. 1 (1924): 11; John S. O'Connor, "The New Scientific Station of Fordham University," Bulletin of the American Association of Jesuit Scientists 2, no. 2 (1924): 1920.

32 "New Telescope at Woodstock," Bulletin of the American Association of Jesuit Scientists 2, no. 1 (1924): 12.

33 "New Seismological Station at the Central Station of the Jesuit Seismological Association," Bulletin of the American Association of Jesuit Scientists 3, no. 5 (1926): 60
} 
Medical Research" in Georgetown, at an estimated cost of $\$ 3,680,000 .{ }^{34}$ George L. Coyle (1869-1932) was responsible for the fundraising campaign. ${ }^{35}$ Head of the Chemistry Department at Georgetown since 1923, Coyle had earned a doctorate in chemistry at Göttingen University in 1907 and had been an active member of the American Chemical Society since his days as a chemistry teacher at Holy Cross (1907-23). " "Financial circumstances in the world of business put a halt to this progress" to erect a building for the institute, so Coyle decided to "engage several laboratories in the new Georgetown Medical School" to work on "the problems of cancer and nephritis." ${ }^{\prime 37}$ In 1933, the White-Gravenor building was inaugurated, and the institute moved into its laboratories. Between 1931 and 1963, the Institute of Chemo-Medical Research at Georgetown made important advances in analytical biochemistry. ${ }^{38}$

The Bulletin reported observations made by Jesuit astronomers, especially at defining moments such as solar eclipses. ${ }^{39}$ Together with astronomy, seismology was a very popular topic in this decade, with the Bulletin paying attention to the work (and distinctions) of Francis A. Tondorf (1870-1929) ${ }^{40}$ and Macelwane. ${ }^{41}$ The Bulletin also took an interest in the activities of Jesuit observatories and stations worldwide, such as the Observatorio del Ebro. ${ }^{42}$ Sometimes, there were descriptions of the cooperation of Jesuit scientists in large-scale projects, as in the case of the determination of world longitude. To determine "the differences of longitude with

\footnotetext{
34 "Proposed New Institute of Georgetown," Bulletin of the American Association of Jesuit Scientists 2, no. 4 (1925): 41

${ }^{35}$ George L. Coyle: born December 11, 1869, Philadelphia; entered December 31, 1887; died January 16, 1932, New York (Richard B. Schmitt, Bulletin of the American Association of Jesuit Scientists 9, no. 3 [1932]: 109-11).

${ }^{36}$ While a teacher of chemistry at Holy Cross, he published three handbooks for his students: George L. Coyle, Notes on Basic Analysis (Worcester, MA: Skelley, 1914); Coyle, Notes on Acid Analysis (Worcester, MA: Skelley, 1915); Coyle, Notes on Dry Analysis (Worcester, MA: Skelley, 1918).

${ }^{37}$ Schmitt, "Rev. George L. Coyle, S.J.," 110.

${ }^{38}$ Joseph E. Early, "Science and Story at Georgetown," in Georgetown at Two Hundred: Faculty Reflections on the University's Future, ed. William C. McFadden (Washington, DC: Georgetown University Press, 1990), 185-99, here 187-88.

39 "The Total Eclipse," Bulletin of the American Association of Jesuit Scientists 2, no. 3 (1924): 26; Edward C. Phillips, "Woodstock," Bulletin of the American Association of Jesuit Scientists 2, no. 3 (1924): 26-27; William C. Repetti, "Poughkeepsie," Bulletin of the American Association of Jesuit Scientists 2, no. 3 (1924): 27; Thomas J. Love, "Buffalo," Bulletin of the American Association of Jesuit Scientists 2, no. 3 (1924): 27-28; "Weston," Bulletin of the American Association of Jesuit Scientists 2, no. 3 (1924): 28.

${ }^{40}$ Francis A. Tondorf: born July 17, 1870, Boston; entered August 14, 1888; died November 29, 1929, Washington, DC (Mendizábal, Catalogus defunctorum, 18,071).

41“"Two Noted Seismologists," Bulletin of the American Association of Jesuit Scientists 4, no. 3 (1927): 33-34; "Father F. Tondorf a Fellow of the Royal Astronomical Society of London," Bulletin of the American Association of Jesuit Scientists 4, no. 4 (1927): 42; "Father Macelwane First Chairman of the Newly Founded Eastern Section of the Seismological Society of America," Bulletin of the American Association of Jesuit Scientists 3, no. 4 (1926): 52.

${ }^{42}$ Patrick Henry Yancey, "The Observation of Earth Currents at the Observatory of the Ebro," Bulletin of the American Association of Jesuit Scientists 3, no. 5 (1926): 55-56.
} 
great accuracy in order to test the permanency of their relative positions and certain possibilities as to movement of the earth's crust," the main stations selected were the Naval Operating Base in San Diego, California; the observatory in Algiers, Algeria; and the Jesuit observatory in Shanghai, China. ${ }^{43}$

For a periodical intended for private circulation, awards or discoveries made by Jesuit scientists worldwide were always worth mentioning. In 1924, for example, the Bulletin described Pierre Teilhard de Chardin's (1881-1955) ${ }^{44}$ first paleontological journey to China during the previous year, where he made an "important discovery of human remains at a depth of sixty meters in a river deposit in Northern Kansu." Two years later, the American Jesuits rejoiced at Chardin's appointment as president of the French Geological Society. ${ }^{45}$ The former director of the Georgetown Observatory (1888-1906) and head of La Specola Vaticana (Vatican Observatory) since 1906, Austrian astronomer Johann Hagen (1847-1930) ${ }^{46}$ was cited on numerous occasions. ${ }^{47}$ In December 1930, the Bulletin was dedicated to his memory for his "untiring devotion to the case of science." 48

Together with a concern with perfecting the teaching of science in their colleges and universities, the first years of the Bulletin reflect the participation of Jesuit scientists in individual, medium (the observation of solar eclipses), and large-scale projects (the Jesuit Seismological Association and the Institute for Chemo-Medical Research at Georgetown) in physics, astronomy, seismology, biology, and chemistry. The announcements of new instruments, stations, observatories, institutes, meetings, awards, and publications "by Ours" were meant to inspire academic excellence.

\footnotetext{
43 "Jesuit Cooperation in the World Longitude Determination," Bulletin of the American Association of Jesuit Scientists 4, no. 1 (1926): 12-13.

${ }^{44}$ Pierre Teilhard de Chardin: born May 1, 1881, Orcines, France; entered March 20, 1899; died April 10, 1955, Aix-en-Provence, France (DHCJ 4:3714-17).

45 "Varia," Bulletin of the American Association of Jesuit Scientists 1, no. 5 (1924): 10-11; "French Jesuit President of the French Geological Society," Bulletin of the American Association of Jesuit Scientists 3, no. 5 (1926): 60.

${ }^{46}$ Johann Georg Hagen: born March 6, 1847, Bregenz, Austria; entered October 1, 1863; died September 6, 1930, Rome, Italy (DHCJ 2:1864-65). See also Agustín Udías, "The Correspondence of Johann Georg Hagen, First Jesuit Director of the Vatican Observatory, with Directors of Jesuit Observatories," Journal of Jesuit Studies 3, no. 2 (2016): 259-78; Sabino Maffeo, La Specola Vaticana: Nove papi, una missione (Vatican City: Pubblicazioni della Specola Vaticana, 2001).

47 "Father Hagen and His Jubilee," Bulletin of the American Association of Jesuit Scientists 1, no. 3 (1924): 3; "Father Hagen Honored by the Holy Father," Bulletin of the American Association of Jesuit Scientists 4, no. 3 (1927): 32-33; "Celebration of Father Hagen's Eightieth Birthday in Rome," Bulletin of the American Association of Jesuit Scientists 4, no. 4 (1927): 41-42.

48 "Rev. John G. Hagen, S.J.," Bulletin of the American Association of Jesuit Scientists 8, no. 2 (1930): 5-6. "With humble recognition of their untiring devotion to the cause of science," the number of December 1930 was dedicated to the memory of John G. Hagen and meteorologist José Algué (1856-1930): Bulletin of the American Association of Jesuit Scientists 8, no. 2 (1930): 4.
} 


\section{The Challenge of Academic Professionalism}

Between 1930 and 1940, the Bulletin was edited by Richard B. Schmitt (18881945). ${ }^{49}$ During his tenure, the journal moved to Loyola College, Baltimore, and membership in the Association of Jesuit Scientists increased to 180 associates. ${ }^{50}$ This period was marked by the creation of a national commission to reform Jesuit colleges and universities in 1931-32. Headed by Macelwane, the Commission of Higher Studies of the American Society of Jesus was formally appointed by Superior General Włodzimierz Ledóchowski (1866-1942, in office 1915-42) in March 1931. ${ }^{51}$ The following August, the commission issued a long report chastising the "inertia of local traditions" and the "inbred opposition of Ours to any change." 52 The Macelwane report, as it came to be known, called for reform in the formation of novices and scholastics and insisted on greater professionalism, academic excellence, and national coordination in higher education. On August 15, 1934, Ledóchowski issued an instruction that followed many of the ideas recommended by the Commission of Higher Studies. The documented requested the creation of a national association of schools headed by a national secretary of education to foster union and cooperation, urged the modernization of administrative practices, and asked superiors to select men for doctoral studies and send them to distinguished universities, preferably (though not necessarily) Catholic. ${ }^{53}$ In the 1920s and 1930s, Catholic higher education had improved significantly in America. In twenty years, the network of Catholic colleges and universities grew from 130 to 193, the number of students enrolled in Catholic schools increased from thirty-four thousand to 164,000 , and there was a wide offer of graduate programs. ${ }^{54}$ Nevertheless, these advances threatened Catholic educational theory and practice, as William P. Leahy convincingly argued. There was a tension between Catholic intellectual tradition and academic professionalism, and Catholic educators were criticized for not being "Catholic enough" and for having "imitated the worst features of secular education and ignored most of the good ones." 55

\footnotetext{
${ }^{49}$ Richard B. Schmitt: born July 14, 1888, Brooklyn; entered July 14, 1906; died August 11, 1945, Poughkeepsie (Mendizábal, Catalogus defunctorum, 23,574).

${ }^{50}$ In 1939, membership of AAJS was as follows: biology (forty-five); chemistry (thirty-eight); mathematics (fifty-three); philosophy of science (fifteen); physics (sixty). The association to a specific section was not exclusive, and there were occasional overlaps between the sections of mathematics, physics, and philosophy and science.

${ }^{51}$ William P. Leahy, Adapting to America: Catholics, Jesuits, and Higher Education in the Twentieth Century (Washington, DC: Georgetown University Press, 1991), 33-65. See also Raymond A. Schroth, The American Jesuits: A History (New York: New York University Press, 2007), 181-82.

${ }^{52}$ O'Donnell, Jesuits in the North American Colonies and the United States, 75.

${ }^{53}$ Leahy, Adapting to America, 53.

${ }^{54}$ Leahy, Adapting to America, 55.

${ }^{55}$ Leahy, Adapting to America, 56.
} 
In 1935, National Secretary of Education Daniel M. O'Connell (18851958) ${ }^{56}$ appointed correspondents from the provinces of Chicago, Missouri, New Orleans, California, and Oregon to AAJS; recommended the Bulletin become a national research journal; and insisted on the creation of a national science institute "in order to bring about a coalition of the provinces of the United States for the advancement of scientific pursuits in Jesuit education." 57 Though it was a "zealous and laudable" project, it was soon dismissed. The members of AAJS were against the formation of both a science institute and a science journal and claimed that the "formation of a national research journal of such a nature as to compete with existing non-sectarian journals [...] is impracticable at the present time." Instead of becoming a national journal, the Bulletin inaugurated a new section dedicated to science and philosophy. ${ }^{58}$

The fourteenth annual meeting of AAJS opened on August 31, 1935 at Holy Cross with an address by Francis W. Power (1893-1944) ${ }^{59}$ entitled "Research in Catholic Schools." ${ }^{60}$ The president of AAJS (1934-35) supported the new decision to send several Jesuits for doctoral studies and claimed that "an active and continuous participation on our part in scientific productive work is badly needed on behalf of our Catholic people." ${ }^{161}$ For Power, however, the major challenge was to overcome the pervasiveness of the conflict thesis of science and religion:

This responsibility and opportunity focusses, I think, on what I said before about the dominating position now held in current thought by scientific men; namely, the universal and unshakable conviction of 99' of educated non-Catholics that the Church is opposed to science on principle - that she is afraid of creative scientific work - that dogma is the procrustean bed upon which science and history must be forced to fit, no matter what violence is done to reason or fact. I consider this the bed-rock difficulty which we as Catholic educators have to face, and I regard it as our prime and foremost responsibility and opportunity that we make an earnest start at demolishing it even though I fear none of us will ever live to see the day when it has been even partially refuted to the satisfaction of non-Catholic scholars. ${ }^{62}$

\footnotetext{
${ }^{56}$ Daniel M. O’Connell: born August 27, 1885, Louisville; entered July 25, 1903; died July 29, 1958, West Baden Springs (DHCJ 3:2845).

${ }^{57}$ Bulletin of the American Association of Jesuit Scientists 13, no. 1 (1935): 5.

${ }^{58}$ Bulletin of the American Association of Jesuit Scientists 14, no. 1 (1936): 16.

${ }^{59}$ Francis W. Power: born June 19, 1893, Worcester; entered September 7, 1919; died December 16, 1944, New York (Mendizábal, Catalogus defunctorum, 23,283).

${ }^{60}$ Francis W. Power, "Research in Catholic Schools," Bulletin of the American Association of Jesuit Scientists 13, no. 1 (1935): 9-16.

${ }^{61}$ Power, "Research in Catholic Schools," 12.

62 Power, "Research in Catholic Schools," 15.
} 
Power argued that the bishops, priests, and religious of previous generations "had no leisure time" nor "time for research work" because they had to deal with the "immediate and pressing problem of keeping the faith alive in their widely scattered flocks." However, that was no longer the case. Jesuit professors needed to adapt to the new "standard on which a college or university professor is judged today," that is, scholarly publications. ${ }^{63} \mathrm{He}$ concluded his address by saying that Jesuit scholars should make an "effort to impress a distinctly Catholic touch upon American culture, which is slowly developing out of the confusion of business and industrial activity going on around us." By equating Jesuit scientists with the founding fathers, Power claimed that the Jesuits were "pioneers in establishing a higher type of intellectual culture." He argued that if they wished to avoid being censured by future generations, they needed to "rise to the occasion and bring all our forces to bear upon it that it may become, as far as we can make of it, an American Catholic culture." $" 64$

To celebrate the fourth centennial of the Society of Jesus, AAJS organized a National Science Convention at Loyola University, Chicago, in 1940. Sixty-three Jesuits attended. American assistant Zacheus J. Maher (1882-1963) ${ }^{65}$ congratulated Schmitt for the event and asserted that the program was "proof that the Jesuits of today are as deeply interested in genuine scientific progress and as proficient in advancing it as were the famous Jesuit men of old." ${ }^{\prime 6}$ The convention opened on September 4, 1940 with an address by Schmitt entitled "Science and Philosophy." 67 Schmitt was one of the most distinguished professors of chemistry in the Society of Jesus. He was a member of the American Chemical Society, the International Association of Chemists, and the American Association for the Advancement of Science. At the time of the convention, he was head of the Department of Chemistry at Loyola College, Baltimore (1926-42). ${ }^{68}$ In the words of Joseph B. Niederl, of New York University, Schmitt was "one of the first scientists of the United States to realize the importance of Micro-Chemistry, particularly quantitative organic micro-analysis." ${ }_{99}$ Beginning in 1932, Schmitt had spent "practically every summer"

\footnotetext{
${ }^{63}$ Power, "Research in Catholic Schools," 14.

${ }^{64}$ Power, "Research in Catholic Schools," 16.

${ }^{65}$ Zacheus J. Maher: born April 10, 1891, Batavia, New York; entered September 7, 1914; died June 9, 1952, New York (DHCJ 3:2473-74).

${ }^{66}$ Zacheus J. Maher, "Letter to Rev. Richard B. Schmitt, S.J.," Bulletin of the American Association of Jesuit Scientists 18, no. 1 (1940): 14.

${ }^{67}$ Richard B. Schmitt, "Science and Philosophy," Bulletin of the American Association of Jesuit Scientists 18, no. 1 (1940): 15-18.

${ }^{68}$ Joseph P. Kelly, "Rev. Richard B. Schmitt, S.J.," Bulletin of the American Association of Jesuit Scientists 23, no. 2 (1945): 37-41.

${ }^{69}$ Kelly, "Rev. Richard B. Schmitt, S.J.," 38.
} 
in Niederl's laboratory doing research, and in 1937, 1940, and 1941 he presented his works at the American Chemical Society. ${ }^{70}$

Schmitt began by recalling the "tireless efforts and successes" of some distinguished Jesuit scientists from the old and new Society, such as Christopher Clavius (1538-1612), Athanasius Kircher (1602-80), Angelo Secchi (1818-78), ${ }^{71}$ and Hagen. ${ }^{72} \mathrm{He}$ then moved to the central claim of his lecture: the "fact-finding of science and the metaphysical reasoning of philosophy are the twin pillars of that temple of truth, which we call Human Knowledge." ${ }^{\prime 3}$ Schmitt was worried about the growth of positivism and the underlying connotation of religion with obscurantism and claimed that the "absence of a true philosophy among scientists is responsible for the warped development in human progress." Science, he added, should not be "heralded as the great torch to illuminate the human mind darkened by superstition and legend," a "panacea for all human ill," or a "substitute for religion." ${ }^{74}$ Schmitt ended his lecture with a definition of a Jesuit scientist:

The Jesuit Scientist is not the Jesuit philosopher or literateur or theologian. $\mathrm{He}$ is not dissipating his energy by research in other fields, but he recognizes that there are philosophers, literateurs and theologians, who contribute by valid methods of research distinct from his own. He recognizes that he shall never see God in the test-tube, but he shall find data there and evidence which through reasoning definitely demonstrates His existence. It is precisely his acknowledgment of the value of metaphysical study, that distinguishes him from the scientists who recognize no methods as valid, but the positivist. ${ }^{75}$

The history of Jesuit science was, arguably, the most ubiquitous topic in the convention. Following two general sessions on the American Jesuits and the centennial

\footnotetext{
70 "Volumetric Dry Combustion Method for Carbon," September 1937, Rochester, NY; "Molecular Weight Determination by Isothermic Methods," September 1940, Detroit, Michigan; "Molecular Weight Determination by Isothermic Micro-distillation," September 1941, Atlantic City, NJ: Kelly, "Rev. Richard B. Schmitt, S.J.," 38-39.

${ }^{71}$ Pietro Angelo Secchi: born June 28, 1818, Reggio Emilia, Italy; entered November 3, 1833; died February 26, 1878, New York (DHCJ 4:3542-43). For a biography, see Ileana Chinnici, Decoding the Stars: A Biography of Angelo Secchi, Jesuit and Scientist (Leiden: Brill, 2019).

${ }^{72}$ Schmitt, "Science and Philosophy," 15.

${ }^{73}$ Schmitt, "Science and Philosophy," 16.

${ }^{74}$ Schmitt, "Science and Philosophy," 17.

${ }^{75}$ Schmitt, "Science and Philosophy," 17-18.
} 
history of Georgetown observatory, ${ }^{76}$ there was a "historical symposium on geophysics and geology" focused on the Jesuits' contributions to geology, meteorology, cartography, and terrestrial magnetism. ${ }^{77}$ The topic resurfaced at the sectional meetings, with two papers on $\operatorname{Kircher}^{78}$ and another on Jesuit biologists. ${ }^{79}$ The most noteworthy paper was by Edward C. Phillips $(1877-1952)^{80}$ on the correspondence of Clavius.

Phillips was one of the brightest mathematicians in the Society of Jesus. In 1908, he earned a doctorate in mathematics at Johns Hopkins University and was elected to the Phi Beta Kappa society. ${ }^{81}$ He studied philosophy (1901-4) and theology (1909-13) at Woodstock College and was ordained to the priesthood in 1912. He taught astronomy, physics, and mathematics at Woodstock (1919-25) and directed the Georgetown Observatory for three years (1925-28). ${ }^{82}$ During that brief period, he studied the occultation of stars by the moon, discussed his findings at the American Astronomical Society, and published his works in the Astronomical Journal. ${ }^{83}$ In 1928, he made a journey to Leiden to attend the third session of the International Astronomical Union and present the first results of longitude measurements carried out at Georgetown (July 5-13, 1928). From Leiden, he visited the observatories of Heidelberg, Manheim, Strasbourg, Milan, and Florence before reaching Rome on July 31, the feast day of Saint Ignatius. He spent almost three weeks in Rome working with Hagen at the Vatican Observatory. While in Rome, he was summoned twice by Ledóchowski who had suddenly decided to appoint

\footnotetext{
${ }^{76}$ James B. Macelwane, "The History of American Jesuits in Science," Bulletin of the American Association of Jesuit Scientists 18, no. 1 (1940): 19-20; Thomas D. Barry, "A Century of Astronomy: The Georgetown University Observatory," Bulletin of the American Association of Jesuit Scientists 18, no. 1 (1940): 20-21.

${ }^{77}$ Alphonse R. Schmitt, "Jesuit Contributions to Meteorology," Bulletin of the American Association of Jesuit Scientists 18, no. 1 (1940): 26; Michael J. Ahern, "The Society and the Geological Sciences," Bulletin of the American Association of Jesuit Scientists 18, no. 1 (1940): 27-28; John P. Delaney, "Jesuit Contributions to Our Knowledge of Sunspots," Bulletin of the American Association of Jesuit Scientists 18, no. 1 (1940): 28; James B. Macelwane, "Map Making and the Society," Bulletin of the American Association of Jesuit Scientists 18, no. 1 (1940): 28; Victor C. Stechschulte, "Terrestrial Magnetism," Bulletin of the American Association of Jesuit Scientists 18, no. 1 (1940): 29.

${ }^{78}$ Joseph M. Kelley, "Musurgia universalis of Athanasius Kircher," Bulletin of the American Association of Jesuit Scientists 18, no. 1 (1940): 58; Vicgtor C. Stechschulte, "The 'Ars Magna Lucis et Umbrae' of Athanasius Kircher, S.J.," Bulletin of the American Association of Jesuit Scientists 18, no. 1 (1940): 59. For an excellent introduction to Kircher, see Paula Findlen, ed., Athanasius Kircher: The Last Man Who Knew Everything (London: Routledge, 2004).

${ }^{79}$ Joseph P. Lynch, "Jesuit Biologists of the Old Society," Bulletin of the American Association of Jesuit Scientists 18, no. 1 (1940): 40.

${ }^{80}$ Edward Charles Phillips: born November 4, 1877, Germantown, Pennsylvania; entered August 14, 1898; died May 9, 1952, Poughkeepsie (DHCJ 3:3122-23).

${ }^{81}$ Hugh J. Biller, "Father Edward C. Phillips, 1877-1952," Woodstock Letters 82, no. 1 (1953): 6591, here 69-70.

${ }^{82}$ Biller, "Father Edward C. Phillips, 1877-1952," 74.

${ }^{83}$ Edward C. Phillips and Thomas D. Barry, "Occultations of Stars by the Moon," Astronomical Journal 38, no. 892 (1927): 51-52; Astronomical Journal 38, no. 903 (1928): 143-44.
} 
him as provincial of the New York-Maryland province. The decision was unexpected because "it seems that another Father had already been appointed to this post." The nomination was "a blow to him," and "it took him some months to grow into it." ${ }^{84}$ The Bulletin echoed the consternation at his appointment in a unique note:

On September 12, 1928, the Rev. Edward C. Phillips, S.J., President of the American Association of Jesuit Scientists (Eastern Section) and Director of the Georgetown University Astronomical Observatory, was installed as Provincial of the Maryland-New York Province. Pleased as we were to have Fr. Phillips as Provincial, we cannot but deplore the fact that the Observatory [of Georgetown] has lost a very able Director and the Association a most capable President. ${ }^{85}$

After his tenure as provincial of the New York-Maryland province (1928-35), Phillips went to Rome as delegate to the Twenty-Sixth General Congregation in 1938. As well as working on the revision of the Ratio studiorum, he also compiled the first modern catalog of Clavius's correspondence. ${ }^{86}$ At the National Science Convention in Chicago, Phillips showed lantern slides of eight original autographs of Clavius preserved at the archives of the Gregorian, including "the earliest autograph letter of Galileo." ${ }^{\prime 7}$ And, the following year, he published the translation of two manuscripts by Clavius on the teaching of mathematics, ${ }^{88}$ and of a letter from Secchi to his mother in $1848 .{ }^{89}$ The journey to Rome had proven successful for his newly found interest in the history of Jesuit science. When he returned to the United States, Phillips served as director of the Graduate School at Georgetown (193943), procurator of the New York province (1943-49), and president of AAJS (1941-46).

\footnotetext{
${ }^{84}$ Biller, "Father Edward C. Phillips, 1877-1952," 76-77.

${ }^{85}$ Bulletin of the American Association of Jesuit Scientists 6, no. 1 (1929): 3.

${ }^{86}$ Edward C. Phillips, "The Correspondence of Father Clavius, Preserved in the Archives of Pontif. Gregorian University," Archivum historicum Societatis Iesu 8 (1939): 193-222. For a modern edition of Clavius's letters, see Christoph Clavius, Corrispondenza, ed. Ugo Baldini and Pier Daniele Napolitani, 7 vols. (Pisa: Università di Pisa-Dipartimento di Matematica, 1992).

${ }^{87}$ Edward C. Phillips, "Original Manuscripts of the Mathematical Works of Christopher Clavius," Bulletin of the American Association of Jesuit Scientists 18, no. 1 (1940): 51.

${ }^{88}$ Edward C. Phillips, "The Proposals of Father Christopher Clavius, S.J., for Improving the Teaching of Mathematics," Bulletin of the American Association of Jesuit Scientists 18, no. 4 (1941): 2038. The two autographs were preserved at the Biblioteca Nazionale Centrale di Roma and were included in the Monumenta paedagogica Societatis Jesu, quae primam Rationem studiorum anno 1586 editam praecessere (Madrid: Typis A. Avrial, 1901), 471-76.

${ }^{89}$ Edward C. Phillips, "An Autograph Letter from Fr. Secchi," Bulletin of the American Association of Jesuit Scientists 17, no. 3 (1940): 128-31. The letter was preserved at the archives of the Gregorian University, Rome.
} 
The program of the convention was diverse and included abstracts on a variety of topics such as the teaching of biology, ${ }^{90}$ analytic chemistry, ${ }^{91}$ petroleum prospecting, ${ }^{92}$ and astrophysics. ${ }^{93}$ Some of the authors, such as John S. O'Connor (1908-54), reported experiments made at secular universities. ${ }^{94}$ To review the "problem of the continuous beta ray spectra and the apparent breakdown of the principle of conservation of energy in certain nuclear processes," O'Connor performed experiments at MIT and Columbia University and confirmed Enrico Fermi's (1901-54) general theory of Beta decay. ${ }^{95}$

In the 1930s and 1940s, the greatest challenge for Jesuit colleges and universities, and Catholic institutions in general, was to conform to the standards of secular higher education and research and not lose its core values (and students). Although AAJS rejected the creation of a national research journal and science institute, many reforms proposed by the Commission of Higher Studies to reform higher education in the United States were implemented, starting with the creation of the Jesuit Educational Association in $1935 .{ }^{96}$ The diversity and quality of the program of the National Science Convention in 1940 reflect the efforts put forth to promote graduate training and original research in chemistry, physics, mathematics, astronomy, and biology.

\section{Science, Religion, and Evolution}

One of the most pervasive topics of the Bulletin was the relations between science and religion. ${ }^{97}$ Ahern, the association's first president, was very much invested in

\footnotetext{
${ }^{90}$ James L. Harley, "A High School Biology Syllabus," Bulletin of the American Association of Jesuit Scientists 18, no. 1 (1940): 36; Paul L. Carroll, "Cross Section Anatomy of the Frog," Bulletin of the American Association of Jesuit Scientists 18, no. 1 (1940): 37-38.

${ }^{91}$ Francis W. Power, "Some Results on Analyzed Samples in Quantitative Analysis," Bulletin of the American Association of Jesuit Scientists 18, no. 1 (1940): 43-44; T. Joseph Brown, "A Comparison of Methods Used in the Determination of Chloramine," Bulletin of the American Association of Jesuit Scientists 18, no. 1 (1940): 44; Richard. B. Schmitt, "Three Micro Methods for Molecular Weight Determinations," Bulletin of the American Association of Jesuit Scientists 18, no. 1 (1940): 46; George M. Tipton, "Quantitative Analysis of Spectrographic Methods," Bulletin of the American Association of Jesuit Scientists 18, no. 1 (1940): 48.

92 James B. Macelwane, "Geophysical Prospecting for Petroleum," Bulletin of the American Association of Jesuit Scientists 18, no. 1 (1940): 26.

${ }^{93}$ John A Tobin, "Cosmic Ray Telescopes," Bulletin of the American Association of Jesuit Scientists 18, no. 1 (1940): 55.

${ }^{94}$ John S. O'Connor: born March 19, 1908, Tulsa, Oklahoma; entered September 2, 1926; died June 28, 1954, Chicago (Mendizábal, Catalogus defunctorum, 26,460).

${ }^{95}$ John S. O'Connor, "Developments in Beta Ray Spectroscopy," Bulletin of the American Association of Jesuit Scientists 18, no. 1 (1940): 54.

${ }^{96}$ Leahy, Adapting to America, 56.

${ }^{97}$ The literature on the relations between science and religion is overwhelming. For an overview, see John Hedley Brooke, Science and Religion: Some Historical Perspectives (Cambridge: Cambridge University Press, 1991). See also Peter Harrison, The Territories of Science and Religion
} 
contradicting the conflict thesis. ${ }^{98}$ Professor of chemistry and geology, he was a member of the American Chemical Society, the American Association for the Advancement of Science, and the American Academy of Arts and Sciences and had a vast amount of experience of public speaking and broadcasting. ${ }^{99}$ In the 1920s, he was invited to give talks at MIT, Boston University, and the Boston Ethical Society. In 1925, he delivered a lecture entitled "What a Scientist-Theologian Believes of Evolution" at Ford Hall Open Forum, Boston, to a live audience of 1,200 and to "radio listeners all over the East." 100 Debates about science and religion also came up frequently in professional societies. Edward C. Phillips, for instance, regarded it as a recurrent topic of discussion at the annual meeting of the American Association for the Advancement of Science in December 1925. Nevertheless, there seemed to be "an encouraging trend of reaction against the materialistic and at times openly atheistic views expressed in former meetings by a number of scientists holding high places in the Association." 101

Very often, the scientific and religious articles concerned, or at least mentioned, Darwinian evolution. ${ }^{102}$ In 1927, German philosopher and theologian Anthony Cotter (1879-1954) published an article about Erich Wasmann's (1859-

(Chicago: Chicago University Press, 2015); Harrison, ed., The Cambridge Companion to Science and Religion (Cambridge: Cambridge University Press, 2010); Ronald L. Numbers, ed., Galileo Goes to Jail and Other Myths about Science and Religion (Cambridge, MA: Harvard University Press, 2010).

${ }^{98}$ On the history of the conflict thesis, see especially Jeff Hardin, Ronald L. Numbers, and Ronald A. Binzley, eds., The Warfare between Science and Religion: The Idea that Wouldn't Die (Baltimore: Johns Hopkins University Press, 2018).

${ }^{99}$ Bernard A. Fiekers, "The Reverend Michael J. Ahern, S.J.: A Biography," Bulletin of the American Association of Jesuit Scientists 29, no. 2 (1952): 43-46.

100 "Lectures by Father Ahern," Bulletin of the American Association of Jesuit Scientists 2, no. 2 (1924): 24; "What a Scientist-Theologian Believes of Evolution," Bulletin 3, no. 2 (1925): 24-25. The lecture at Ford Hall was broadcast by WBZ and WBZA. The lecture lasted fifty minutes, and there were fifty minutes of questions and answers. Questions and comments were telegraphed by radio listeners via a special line to the hall.

${ }^{101}$ Edward C. Phillips, "The Kansas City Meeting of the American Association for the Advancement of Science and of Affiliated Societies," Bulletin of the American Association of Jesuit Scientists 3, no. 3 (1926): 34-36, here 36.

${ }^{102}$ The Catholic Church reacted somewhat ambivalently toward evolution. Despite not issuing any documents condemning evolution, the church discouraged the discussion of the topic. For an overview, see Mariano Artigas, Thomas F. Glick, and Rafael A. Martínez, Negotiating Darwin: The Vatican Confronts Evolution, 1877-1902 (Baltimore: Johns Hopkins University Press, 2006). For the particular cases of Eric Wasmann (1859-1931) and John Zahm (1851-1921), see James R. Hofmann, "Erich Wasmann, S.J.: Natural Species and Catholic Polyphyletic Evolution during the Modernist Crisis," Journal of Jesuit Studies 7 (2020): 244-62; John P. Slattery, Faith and Science at Notre Dame: John Zahm, Evolution, and the Catholic Church (Indiana: University of Notre Dame Press, 2019). For a history of the debate about teaching evolution in America see Edward J. Larson, Summer for the Gods. The Scopes Trial and America's Continuing Debate Over Science and Religion (New York: Basic Books, 1997), Ronald Numbers, The Creationists: From Scientific Creationism to Intelligent Design (Cambridge, MA: Harvard University Press, 2006). 
1931) controversial views on evolution. ${ }^{103}$ For Cotter, Wasmann refuted those who regarded evolution as an alternative to religion and, specifically, to the account of creation as narrated in the Genesis. On the one hand, "evolution is a heuristic principle, to be kept in mind by the scientist and to be applied only if and as far as the facts warrant." On the other, he paraphrased Galileo's words to Archduchess Christina of Lorraine (1565-1637) in 1615 and asserted that "the Bible was never meant to teach us science." Wasmann claimed that the facts narrated in the scriptures, including the ones in the first chapters of Genesis, were not myths but historical facts, narrated "in a language intelligible to men of all times" and independent of future scientific theories. ${ }^{104}$ Cotter concluded his synopsis with the remark that "Wasmann is not an evolutionist at all, viz. in the sense in which this term is understood here in America." 105

The debates around evolution continued in the following decades. In 1935, Power was troubled by the wide acceptance of evolution in secular circles, academic publications, popular science, and the public press. ${ }^{106}$ The following year, former editor Henry Brock argued that the positivistic conjecture claiming that "evolution was to take the place of God and science would solve all men's problems" had clearly missed the mark. In his words, "time has tended to convince the unprejudiced not only that the Church is not opposed to science and hence there can be no true conflict, but also that science cannot take the place of religion." 107 In 1950, Pope Pius XII (1876-1958, r.1939-58) formally allowed Catholics to discuss "the doctrine of evolution, in as far as it inquires into the origin of the human body as coming from pre-existent and living matter." 108 Two years later, the Bulletin published an article on the "synthetic theory of evolution," asserting that the many shadows in the knowledge of evolution were both inevitable and good because they encouraged further research. ${ }^{109}$

Closely related to the debates on evolution were the ones on eugenics. In 1925, Raymond J. McWilliams (1893-1946) ${ }^{110}$ warned against "restricted immigration, segregation and inhibition of undesirables, selective breeding and

\footnotetext{
${ }^{103}$ Anthony C. Cotter (Kottermair): born September 21, 1879, Ainried (Bavaria), Germany; entered October 20, 1899; died June 13, 1954, Boston (DHCJ 2:985); Eric Wasmann: born May 29, 1859, Meran, Austria; entered September 29, 1875; died February 27, 1931, Valkenburg, Netherlands (DHCJ 4:4016-18).

${ }^{104}$ Anthony C. Cotter, "Fr. Erich Wasmann on Evolution," Bulletin of the American Association of Jesuit Scientists 4, no. 3 (1927): 27-31, here 28.

${ }^{105}$ Cotter, "Fr. Erich Wasmann on Evolution," 30.

${ }^{106}$ Power, "Research in Catholic Schools," 13.

${ }^{107}$ Henry M. Brock, "Some Limitations of Physical Science," Bulletin of the American Association of Jesuit Scientists 14, no. 1 (1936): 8-14, here 8.

${ }^{108}$ Pius XII, Humani generis, August 12, 1950, no. 36.

109 Joseph Franklin Ewing, "The Synthetic Theory of Evolution," Bulletin of the American Association of Jesuit Scientists 29, no. 2 (1952): 47-58, here 55.

${ }^{110}$ Raymond J. McWilliams: born January 22, 1893 Paterson; entered January 12, 1913; died February 12, 1946, New Jersey (Catalogs of the Province of Maryland-New York [1914-1930]; "Rev.
} 
outbreeding." This kind of "loose thinking" was tragic and had already led to the passing of state laws for vasectomy and phallectomy of certain classes. ${ }^{111}$ When McWilliams wrote his essay, the Supreme Court was already ruling on the controversial case Buck v. Bell (1924-27), which allowed for compulsory sterilization of the unfit. For McWilliams, eugenics was a "nefarious bomb" that was about to explode. To fight it should not be a concern of a minority but of all true Americans:

If one feels the pulse of Jews, Negroes and Irish Roman Catholics as recorded in their various periodicals, the charge of a subtle $\mathrm{Ku}$ Klux Klanism, of unwarranted arrogance, and scientific pish-posh seems well founded. These representatives have all sensed the same thing and attacked it. Though the names they give it and the standpoints from which they assail it differ, they are all agreed that it is a hateful thing, a nefarious bomb to prevent the explosion of which is the concern of all true Americans. ${ }^{112}$

\section{The Jesuit Science Bulletin}

Between 1941 and 1961, the Bulletin had three editors, and membership of AAJS expanded to more than two hundred associates (see table 1). ${ }^{113}$ During Bernard A. Fiekers's (1906-73) $)^{114}$ second term as editor-in-chief(1956-61), the journal carried the heading Jesuit Science Bulletin (see fig. 4). In the 1950s, many Jesuits were sent for doctoral studies at Harvard, Johns Hopkins, Stanford, MIT, St. Louis, Fordham, and the Catholic University of America. ${ }^{115}$ During those years, Bulletin reflected not only the Jesuits' research in chemistry, biology, physics, and mathematics but also their efforts to attract competitive funding. In 1953, for instance, the journal reissued a pamphlet by the Office of Research Services at Fordham University on how to prepare a grant application. ${ }^{116}$

Raymond Joseph McWilliams, Native Patersonian, Dies in Jersey City,” Morning Call [February 13, 1946]).

${ }^{111}$ Raymond J. McWilliams, "Nordics, Supermen, Race, and Recent Scientific Literature," Bulletin of the American Association of Jesuit Scientists 3, no. 3 (1926): 38-39.

${ }^{112}$ McWilliams, "Nordics, Supermen, Race and Recent Scientific Literature."

113 The last list of members of AAJS was published in 1949. That year, the association counted 206 associates.

${ }^{114}$ Bernard A. Fiekers: born January 19, 1906, Cambridge, MA; entered September 7, 1927; died January 9, 1973, Worcester (Verástegui, Catalogus defunctorum, 132).

${ }^{115}$ Homann, "Source for the History of American Catholic Education," 31.

116 "How to Prepare Applications for Grants-in-Aid for Research Projects," Bulletin of the American Associational of Jesuit Scientists 32, no. 2 (1955): 31-37. 


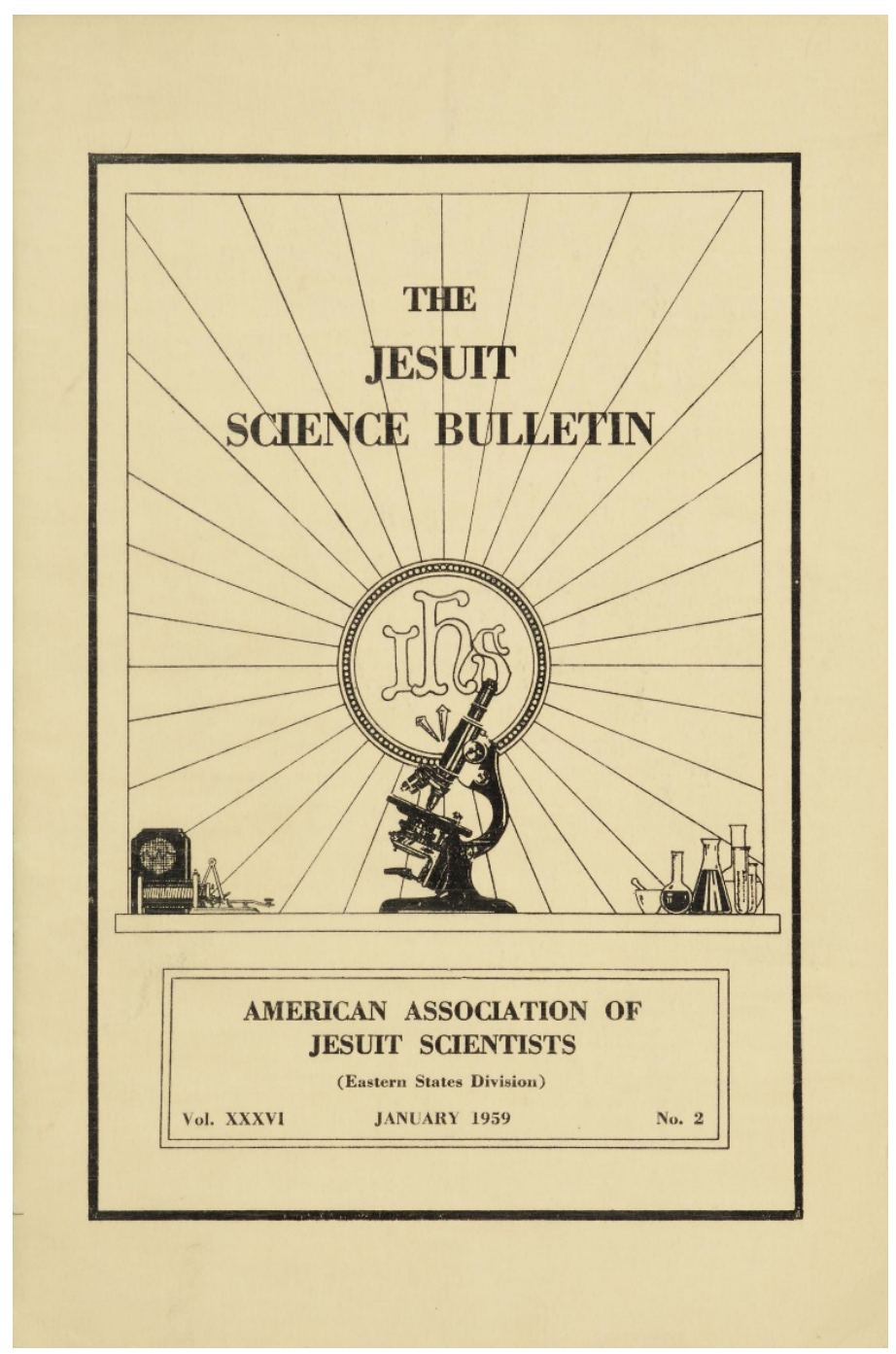

Figure 4. The Jesuit Science Bulletin 36, no. 2 (1959).

Thirty years after the Bulletin's foundation, the lack of Catholic scientists was presented in the popular press as proof of the opposition between religion and science. At the twenty-eighth annual meeting of AAJS, John P. Delaney (1906-56) ${ }^{117}$ commented on an article published in the Catholic Digest. In August 1953, the wellknown member of the Atomic Energy Commission Thomas Edward Murray (1891-1961) had criticized the "scarcity of Catholics among atomic scientists." 118 Delaney claimed that all "Catholic educators should be gravely concerned by this situation because it depreciates publicly all Catholic education." But unlike Murray,

\footnotetext{
117 John P. Delaney: born March 6, 1906, Liverpool, England; entered February 1, 1922; died January 12, 1956, Baguio, Philippines (DHCJ 2:1070-71).

118 John P. Delaney, "The Atom and the Cross," Bulletin of American Association of Jesuit Scientists 31, no. 1 (1953): 8-10, here 8.
} 
the solution for Delaney was not to build "million dollars cyclotron in Jesuit colleges." The problem had not been the shortage of cyclotrons or science facilities, in general, but rather of "Catholic scientists to assist in the interpretation of data from cyclotrons." 119 Delaney then called for an "awakened Jesuit interest in science," arguing that it would enrich "sermons and retreats" and, more importantly, "inspire more Catholic students towards science careers."

In 1961, the editors made a few adjustments to the Bulletin in response to some suggestions during the annual meeting of AAJS at Holy Cross College in August 1960. ${ }^{121}$ The committee reported the "unfavorable reactions of externs to the Society's scientific work as presented in the Bulletin," noted the "difficulty of obtaining suitable copy," and "offered suggestions concerning the journal's content." Because the "restricted nature of its circulation" was "an immediate corollary" of the constitutions and history of AAJS, the editors decided to elaborate only on the recommendations on content and clarified the guidelines for future issues. ${ }^{122}$ From that moment on, the Bulletin was to publish only material that was "of specific interest to Jesuit scientists," including news regarding science and education in their colleges, high schools and scholasticates, obituaries of Jesuit scientists, and a new section featuring interviews with Catholic scientists and educators. ${ }^{123}$ During these final years, the Bulletin printed a series of testimonies of "priest-scientists" to inspire young Jesuits to follow a scientific career. ${ }^{124}$ In 1963, the association conducted a nationwide survey of programs in science and engineering in Jesuit colleges and universities to provide useful information for prospective students. ${ }^{125}$ The results reflected the role that science had gained in Jesuit education since the 1920s. In 1963, there were 117 modern science departments in Jesuit colleges and universities nationwide, modern and pre-engineering programs that ranged from nautical and chemical engineering to theoretical and

\footnotetext{
119 Delaney, "Atom and the Cross," 8.

${ }^{120}$ Delaney, "Atom and the Cross," 9.

121 "The Bulletin: An Editorial," Bulletin of the American Associational of Jesuit Scientists 38, no. 1 (1961): 1-3.

122 "Bulletin: An Editorial," 1.

${ }^{123}$ See, for instance, the interview with Catholic phycologist and educator Sister Annette Walters: James F. Smith, "The Jesuit Role in the Scientific Training of Sisters: Sister Annette Walters, C.S.J.," Bulletin of the American Association of Jesuit Scientists 38 (1961): 64-70.

${ }^{124}$ Frank R. Haig, "The Vocation of the Priest-Scientist," Bulletin of the American Association of Jesuit Scientists 38 (1961): 3-9; Ernest G. Spittler, "The Priest-Scientist in the Church," Bulletin of the American Association of Jesuit Scientists 39 (1962): 30-37; William W. Meissner, "The Jesuit as Priest-Scientist," Bulletin of the American Association of Jesuit Scientists 40 (1963): 25-33.

125 "A Survey of Science Education in Jesuit Colleges and Universities," Bulletin of the American Association of Jesuit Scientists 40, no. 2 (1963): 66-148; "A Survey of Pre-engineering and Engineering Education in Jesuit Colleges and Universities," Bulletin of the American Association of Jesuit Scientists 40, no. 3 (1963): 152-71.
} 
applied mechanics. Science education and research in Jesuit colleges and universities had improved significantly since the first meeting of the association at Canisius College in 1922.

In 1966, AAJS published the last issue of the Bulletin. For forty-three years, the Bulletin of the American Association of Jesuit Scientists published a great variety of articles, including research articles on mathematics, astronomy, chemistry, physics, biology, and seismology, short news stories and reports, and essays on the relations between science and religion. Because the association was established to foster science education at Jesuit colleges, the topic was widely covered. The articles proposed new experimental courses, suggested new literature, and analyzed the role of high school education in the training of future scientists. Besides publishing obituaries and biographies of celebrated Jesuit scientists, the quarterly also welcomed articles on the history of Jesuit science. The research articles covered contemporary issues ranging from Fermat's last theorem to nuclear disintegration and cellular metabolism. These articles reflected not a theoretical interest but the actual practices of Jesuit scientists in modern physics, chemistry, and biology during this period. Finally, one of the most recurrent topics was the construction of centers, departments, laboratories, observatories, and stations in Jesuit institutions.

\section{Building a Catholic Culture}

Why did Jesuit schools fail to develop first-rate science programs, as Homann contended in $1984 ?^{126}$ In other words, why did Catholic institutions consistently rank below secular universities? A history of American higher education and a reading of the Bulletin of the American Association of Jesuit Scientists allow us to make further considerations on the lack of prestige of Catholic science and education in America.

During the First World War, American scientists made significant contributions to military science, including submarine detection and ballistics. In the aftermath of the war, "the American experience was euphorically regarded as a vindication of American science." ${ }^{127}$ In the interwar period, the National Research Council, assisted by the Carnegie Corporation and the Rockefeller Foundation, became a cornerstone for American science. Before the Second World War, very few universities engaged in research and graduate education. According to science journalist Edwin E. Slosson (1865-1929), the fifteen Great American Universities

\footnotetext{
${ }^{126}$ Homann, "Source for the History of American Catholic Education," 33.

${ }^{127}$ Roger L. Geiger, The History of American Higher Education: Learning and Culture from the Founding to World War II (Princeton: Princeton University Press, 2015), 484.
} 
(New York, 1910) were Columbia, Harvard, Pennsylvania, Princeton, Yale, California, Illinois, Michigan, Minnesota, Wisconsin, Chicago, Cornell, Johns Hopkins, MIT, and Stanford. ${ }^{128}$ In the 1920s, the ten leading private research universities averaged $\$ 25$ million in annual donations. By the turn of the decade, this figure had risen to $\$ 60$ million, with Harvard and Yale claiming two-thirds of these funds. ${ }^{129}$ During this period, the most preeminent universities were Harvard, Chicago, and Columbia, followed by Yale, Princeton, Michigan, California, and Wisconsin. In terms of medical science, Johns Hopkins led the field. Finally, there came Stanford, Penn, Minnesota, and Illinois, which operated on a lower level. ${ }^{130}$ During the interwar years, American science flourished. With the consecutive recruiting of Ernest O. Lawrence (1901-58) and J. Robert Oppenheimer (1904-67) in 1928 and 1929, the University of California became the leading institution in nuclear physics. ${ }^{131}$ Research in biochemistry, genetics, and molecular biology developed in medical schools and led to the attribution of twelve Nobel prizes between 1925 and 1950. ${ }^{132}$

As Roger L. Geiger has argued, the academic revolution "posited the systematic pursuit of new knowledge" as the central mission of universities. However, "generating new knowledge through research and education required a scale of operation and expenditure that only a handful of universities could achieve." 133 The revolution was unavoidable, but its pace and impact on higher education were not straightforward. The explanation, according to Geiger, was threefold. First, before 1940, there were only sixteen research universities in America - the fifteen institutions acknowledged by Slosson in 1910 and Caltech. Second, foundations, especially Carnegie and Rockefeller, concentrated their investments in a small number of universities. Finally, the processes of organizing graduate education based on merit rather than social register and the adoption of academic criteria for hiring and promoting faculty were particularly slow. ${ }^{134}$

After the Second World War, MIT, Caltech, Harvard, California, and Chicago expanded significantly thanks to the Office of Naval Research and the Office of Scientific Research and Development. ${ }^{135}$ The latter disbursed $\$ 100$ million to

\footnotetext{
${ }^{128}$ Geiger, History of American Higher Education, 348.

${ }^{129}$ Geiger, History of American Higher Education, 492.

${ }^{130}$ Geiger, History of American Higher Education, 496. For the case of Stanford, see Rebecca S. Lowen, Creating the Cold War University: The Transformation of Stanford (Berkeley, CA: University of California Press, 2010). See also James G. Hershberg, James B. Conant: Harvard to Hiroshima and the Making of the Nuclear Age (New York: Knopf, 1993).

${ }^{131}$ J. [John] L. Heilbron and Robert W. Seidel, Lawrence and His Laboratory: A History of the Lawrence Berkeley Laboratory, vol. 1 (Berkeley: University of California Press, 1989).

${ }^{132}$ Geiger, History of American Higher Education, 529.

${ }^{133}$ Geiger, History of American Higher Education, 546.

${ }^{134}$ Geiger, History of American Higher Education, 547.

${ }^{135}$ Roger L. Geiger, American Higher Education since World War II: A History (Princeton: Princeton University Press, 2019), 74-75. See also Geiger, "Science, Universities, and National Defense, 1945-1970," Osiris 7 (1992): 26-48.
} 
MIT alone, which made it the largest beneficiary of postwar funds. The runner-up was the University of California, Berkeley, where Lawrence built the first cyclotron. ${ }^{136}$ When the National Science Foundation was created in 1950, the overwhelming majority of its funding came from the Pentagon and the Atomic Energy Commission. Between 1958 and 1963, the federal funds for research increased from $\$ 200$ to $\$ 800$ million. ${ }^{137}$ In this period, the sixteen research universities attracted most of the new federal funds. This self-sustaining system led to a stable hierarchy of universities in the twentieth century and to inequality in endowment, publications, and prestige that persisted into the twenty-first. ${ }^{138}$

Catholic higher education improved considerably after the Second World War. Catholic schools gained millions of dollars from the federal government, which allowed them to expand significantly. In 1967, Catholic universities and colleges obtained $\$ 125$ million in research grants and contracts. ${ }^{139}$ Unlike the sixteen research universities, these funds were not concentrated but were dispersed by a large number of institutions. The Jesuits alone ran nine colleges and nineteen universities in this period, which means that if these funds were equally distributed each college would have less than $\$ 4.5$ million for research. One of the larger issues with the lack of prestige of Catholic higher education was the indistinctiveness in American intellectual culture, despite nearly four decades of labor. ${ }^{140}$ According to Leahy, the main reasons for this status were the overexpansion and duplication of graduate programs, the lack of an effective national leadership, and the preference given to teaching and ministry over research and academic excellence. ${ }^{141}$

The contrast between Jesuit colleges and contemporary secular universities was identified in the early 1930s by the Commission of Higher Studies. But to take the words of the Macelwane report as compelling proof of the inadequacy of Jesuit science in the following three decades is unreasonable. The concentration of funding in the sixteen research universities, first by the foundations in the interwar period and then by federal agencies after the Second World War, made the rise of academic excellence, the promotion of graduate education and research, and the race for prestige uneven. A survey of the Bulletin allows us to make further considerations. Stamping a "distinctly catholic touch upon American culture" while promoting academic excellence was a difficult challenge. ${ }^{142}$ But Jesuit scientists did not live in a self-imposed ghetto. Likewise, they did not lack industry or engage

\footnotetext{
${ }^{136}$ Geiger, American Higher Education, 77-78. See also David Kaiser, ed., Becoming MIT: Moments of Decision (Cambridge, MA: MIT Press, 2010).

${ }^{137}$ Geiger, American Higher Education, 94-95.

${ }^{138}$ Geiger, American Higher Education, 364.

${ }^{139}$ Leahy, Adapting to America, 134.

${ }^{140}$ Leahy, Adapting to America, 135.

${ }^{141}$ Leahy, Adapting to America, 138-47.

${ }^{142}$ Power, "Research in Catholic Schools," 16.
} 
in poor working habits. ${ }^{143}$ That they were not building \$100 million cyclotrons and doing research in nuclear physics, attracting a big portion of funding from foundations or federal agencies, or engaging in postwar academic research in this period must not underestimate their contributions to science. Since the 1920s, American Jesuits had coordinated or participated in intermediate and large-scale science projects - such as the Jesuit Seismological Association at St. Louis and the Institute for Chemo-Medical Research at Georgetown - received graduate education at secular universities, joined and presented their research at professional societies, and were acknowledged for their works, especially in astronomy, astrophysics, chemistry, biology, and seismology.

${ }^{143}$ Ellis, “American Catholic and the Intellectual Life,” 385-86. 